$<$ 症例報告 $>$

\title{
静岡県西部地区で発生したシカ生肉またはイノシシ生肝摂食後の $\mathrm{E}$ 型急性肝炎 3 例
}

\begin{tabular}{|c|c|c|c|c|}
\hline 欣也 ${ }^{1) *}$ & 小林 & 良正 ${ }^{1)}$ & 高橋 和明 ${ }^{2)}$ & 早田 謙一1) \\
\hline 信一1) & 川田 & 一仁1) & 高橋百合美1) & 牧野さつき1) \\
\hline 秀尚 ${ }^{1)}$ & 中村 & 浩淑 ${ }^{1)}$ & 安倍 夏生 ${ }^{2)}$ & 新井 雅裕 ${ }^{2)}$ \\
\hline
\end{tabular}

\begin{abstract}
要旨 : シカ及びイノシシの生食により感染したと思われる $\mathrm{E}$ 型急性肝炎 3 例を経験したので報 告する. 症例 1,2 は 71 歳と 48 歳の男性で発症の約 2 力月前に, 偶然同一飲食店で別々にイノ シシの肝を生食していた. 症例 3 は 69 歳の男性で, 発症の 2 力月前から息子が狩編で捕獲した 複数頭のシカ生肉を頻回に自宅で調理し摂取していた. 3 症例とも入院時, 肝逸脱酵素は著明に 上昇していたが補液や安静で改善した. 3 症例の病初期血清における IgM-HEV 抗体, IgG-HEV 抗体, HEV-RNA が陽性で HEV genotype は 4 型, 塩基配列は相互に $99.8 \%$ 以上一致した. 愛 知県のヒト及びイノシシから分離されている「4 型 HEV 愛知株」との間にも $98.5 \%-99.8 \%$ の 一致率を示し, 北海道に蔓延する genotype 4 とは明らかに別系統であることが注目された.
\end{abstract}

索引用語：急性肝炎 $\mathrm{HEV}$ E型肝炎

\section{はじめに}

E 型肝炎ウイルス (HEV) 日本固有株の存在が報告 された 2001 年以後, 国内感染例がしばしば報告される ようになり, 2006 年には我国に於ける HEV 感染の全国 集計が報告された ${ }^{12)}$. 急性肝炎診断の際, 海外渡航歴 が無くともイノシシやブタ, シカ肉の摂取歴があれば, $\mathrm{E}$ 型急性肝炎を意識し HEV 関連抗体の測定を行う様に なった事は, 報告例増加の一因であると考えられる. 加熱処理の不十分なイノシシ, ブタ, シカの肉や内臓 の摂取が感染経路となる事は, 一般には未だに認識さ れていない為か発症例は後を絶たない.

今回, 静岡県西部地区に扔いて飲食店で提供された 野生イノシシの肝と, 自宅で調理した野生シカ肉が感 染源として疑われた $\mathrm{E}$ 型急性肝炎 3 症例を経験し, そ の塩基配列の検討を行ったので報告する.

1）浜松医科大学第二内科

2) 東芝病院研究部

${ }^{*}$ Corresponding author: k7@hama-med.ac.jp

<受付日2010年1月12日 ><採択日2010年6月29日 >

\section{症例 1}

患者：71 歳, 男性.

主訴：全身倦䍐感, 食欲低下.

既往歴：64 歳, 交通事故で右腎損傷. 67 歳带状疮疹.

家族歴：特記事項なし.

飲酒歴：ビール大ビン 1 本 $/$ 日 $\times 50$ 年.

輸血歴, 海外渡航歴, 内服薬 : なし.

現病歴：2006 年 12 月末に浜松市天竜区の某飲食店に て野生イノシシのレバーを生食した。 2007 年 2 月 14 日頃から感冒様症状があり, 2 月 22 日 A 病院を受診し た. 総合感冒薬と抗生剂を処方されたが, 改善しない 為に再受診したところ, 肝機能異常を指摘され，精査 加療目的で 3 月 12 日に A 病院に入院した. 入院時の T-Bil 值が高值で重症化が懸念され, 翌日当院に転院と なった.

現症 : 身長 $145 \mathrm{~cm}$, 体重 $47 \mathrm{~kg}$, 体温 $37.1^{\circ} \mathrm{C}$, 血圧 $153 / 99 \mathrm{mmHg}$, 脈拍 84 /分整. 貧血, 浮腫なし. 眼球 結膜, 皮虐に黄疸を認める. 表在リンパ節を触知せず. 胸部聴診上異常なし、腹部は平坦, 軟, 心窩部に圧痛 あり. 右季肋部に肝を 1 横指触知する. 脾を触知せず. 神経学的異常所見なし.

血液検査所見：T.Bil, トランスアミナーゼが著明に 
上昇していた. IgM-HEV 抗体, IgG-HEV 抗体は共に陽 性であった（Table 1).

肝組織所見：第 3 病日に施行した肝生検では，門脈 域のリンパ球浸潤と広範な肝細胞の壊死炎症反応を認 めた.

入院後経過：入院時血液検査にて, IgM-HEV 抗体, IgG-HEV 抗体が陽性であったことから急性 E 型肝炎と 診断した. 感染源として発症の約 7 週前, 2006 年 12 月末のイノシシのレバーの生食が疑われた。入院時に 食欲低下を認めたが, 数日間の補液で症状は改善した. 肝機能異常も徐々に改善し, 第 17 病日にトランスアミ ナーゼが 200 台まで低下した為退院した。退院約 2 カ 月後に肝機能は正常化した.

\section{症例 2}

患者：48 歳男性.

主訴: 全身倦急感, 右季肋部痛.

既往歴 : 28 歳, A 型急性肝炎. 36 歳, 慢性骨髄性白 血病.

家族歴 : 父, 高血圧, 膵臟癌.

飲酒歴：日本酒 3 合 $/$ 日を週 2 日 $\times 20$ 年.

輸血歴：なし.

内服薬：ニフェジピン，アロプリノール，カルデサ ルタンシレキセチル, フロセミド, ジピリダモール，

メシル酸イマチニブ.

現病歴 : 2006 年 12 月に症例 1 と同じ飲食店でイノシ シのレバーを生食していた. 2007 年 2 月 23 日頃から上 腹部痛と下痢の症状があり, $\mathrm{A}$ 病院で制酸剤, 抗生剂, 整腸剂を処方された，症状は一旦軽快したが，3月 12 日頃から全身倦意感, 微熱, 右季肋部痛が出現した.

3 月 16 日, $\mathrm{A}$ 病院を再受診し, 血液検査にて肝機能異 常を認め精查加療目的で同日当院に紹介入院となった.

現症：身長 $164 \mathrm{~cm}$, 体重 $76 \mathrm{~kg}$, 体温 $37.0^{\circ} \mathrm{C}$, 血圧 $128 / 70 \mathrm{mmHg}$ ，脈拍 80/分整．貧血，浮腫なし．眼球 結膜に黄疸を認める．表在リンパ節を触知せず．胸部 聴診上異常なし，腹部は平坦，軟，心窩部から右季肋 部に圧痛あり。右季肋部に肝を 1 横指触知する。脾を 触知せず．神経学的異常所見なし，

血液検査所見：T.Bil とトランスアミナーゼの上昇を 認めた。症例 1 と偶然同一店でイノシシのレバーを摂 取していた事から IgM-HEV 抗体, IgG-HEV 抗体の測 定を行い，いずれも陽性であった（Table 1).

腹部 CT 所見：胆囊壁の肥厚，肝内門脈周辺に浮腫 状変化を認めた.
入院後経過 : 入院時の血液検査にて, IgM-HEV 抗体, IgG-HEV 抗体が陽性であり急性 E 型肝炎と診断した. 感染源として, 発症の約 8 週前, 2006 年 12 月末のイノ シシレバーの生食が疑われた。全身倦急感や右季肋部 痛は, 入院後に安静のみで軽快し, 肝機能異常も徐々 に改善した. 第 12 病日にはトランスアミナーゼは 100 以下まで低下し退院となった。退院約 1 力月後に肝機 能は正常化した。

\section{症例 3}

患者：69 歳男性.

主訴 : 無し. 肝機能異常の精査加療目的で入院.

既往歴：60 歳, 墨性リンパ腫（Diffuse large B cell） で自己末梢血幹細胞移植施行. 66 歳 2 型糖尿病.

家族歴：特記事項なし。

飲酒歴：ウイスキー水割り 1 杯/日.

輸血歴, 海外渡航歴：なし。

内服薬：テルミサルタン，ボグリボース.

現病歴：2007 年 11 月頃から息子が狩編で浜松市天竜 区にて捕獲した野生イノシシ, シカのうち複数頭のシ 力肉を頻回に生食していた. 2007 年 11 月 26 日糖尿病 に対する定期受診時の肝機能検查は正常であった. 2008 年 1 月 28 日に再受診し, 血液検査で肝機能異常を認め た、ボグリボースによる薬剤性肝障害を疑い中止した が改善せず, 2 月 10 日精查加療目的で当科に入院となっ た。

現症：身長 $157 \mathrm{~cm}$, 体重 $56 \mathrm{~kg}$, 体温 $36.6^{\circ} \mathrm{C}$, 血圧 163/89 mmHg, 脈拍 108/分整. 貧血, 黄疸, 浮腫なし. 表在リンパ節を触知せず．胸部聴診上異常なし．腹部 は平坦，軟，圧痛なし，肝，脾を触知せず．神経学的 異常所見なし。

血液検査所見：トランスアミナーゼは著明に上昇し ていたが, T.Bil は正常, 凝固能も保たれていた，発症 8 週前から複数頭のシカの生肉を頻回に摂取していた事 から, IgM-HEV 抗体, IgG-HEV 抗体の測定を行い,い ずれも陽性であった（Table 1).

入院後経過：E型急性肝炎と診断し, 安静のみで経過 観察した。 入院中も特に症状は無く肝機能異常は改善 した。第 15 病日にはトランスアミナーゼは 50 台まで 低下し退院となった。退院約 1 力月後に肝機能は正常 化した。

症例 1,2 は偶然, 同一飲食店で提供されたイノシシ の生レバーを発症の 7,8 週前に摂取していた. 同飲食 店に問い合わせたところ，レバーは提供した日の直前 


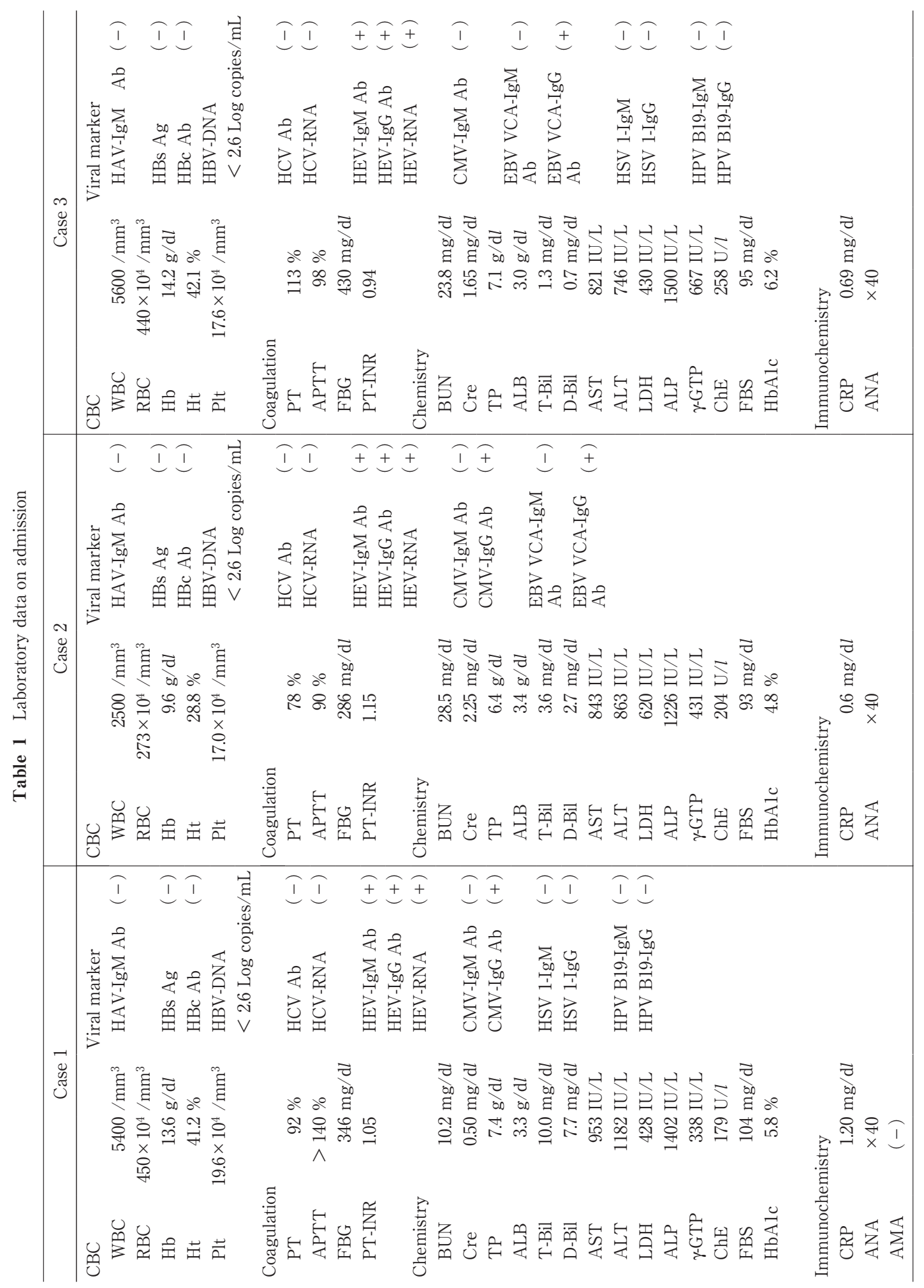


に天竜区で狩猟された一頭分をもらい受け同店で調理 し出されたものであった。同飲食店には当時の内臟や 肉の保存は無く, 感染源の完全な特定には至らなかっ た. 症例 3 は, 患者の息子が野生シカを 2007 年 11 月〜 2008 年 2 月までに計 11 頭捕獲し, そこから数頭分の肉 を自宅に持ち帰り，患者が頻回に摂取し感染が成立し たと推測されたが，残った肉は無く感染源は特定でき なかった. 同居している息子夫婦と 3 人の孫のうち生 で肉を摂取した者はいなかった，息子夫婦と孫 2 人の 計 4 人については同意を得て血清を採取し感染の有無 を調査したが既感染を含めて全員陰性であった。

HEV 抗体・HEV-RNA の測定 : IgM-HEV 抗体㧍よび IgG-HEV 抗体, HEV-RNA の測定は入院時の保存血清 を用いておこなったＩgM-HEV 抗体および IgG-HEV 抗体はリコンビナント HEV 抗原タンパク質を使用した EIA 法による IgM クラスと IgG クラス抗 HEV 抗体検 出キット (特殊免疫研究所製造)によって測定した ${ }^{3)}$. HEV-RNA は保存血清から RNA を抽出し, ORF1 内に 設定した二カ所のプライマーセット4) を用いて RT-PCR を行い, 得られた PCR 産物から 326 塩基, 821 塩基の 配列を決定し, 既報株の塩基配列と比較検討した。

3 症例について HEV 塩基配列の完全長化を試み, 症 例 1 （JKS-Shiz07L：AB521805）と症例 3（JYN-Shiz 08L : AB521806) は 7219 塩基の準完全長 HEV 塩基配 列が得られた，症例 2 は ORF1 の 326nt (JSI-Shiz07 : AB521807)と 821nt (JSI-Shiz07R：AB521808)の部分 配列を得た。症例から分離された HEV-RNA は何れも genotype 4 型に所属し，これら静岡株は相互に $99.8 \%$ 以上の一致を示した。 また愛知県の患者と設楽地区で 捕獲されたイノシシから分離されている「4 型 HEV 愛知株」とは $98.5 \%-99.8 \%$ の一致率であり, 分子系統 樹解析 (Fig. 1)にて同一系統株であることが判明した. 上記の静岡県から分離した準完全長 2 株(JKS-Shiz07L, JYN-Shiz08L) を既報の完全長及び準完全長 HEV 塩基 配列株と比較したところ，上海旅行帰りの患者 (E067SIJ05C) と上海のブタ (SH-SW-zs1) から分離された上 海株(6)との間で $90.2 \%-92.0 \%$ の一致率を示した.アミ ノ酸配列について比較（Fig. 2）したところ，この 4 株(JKS-Shiz07L, JYN-Shiz08L, E067-SIJ05C, SH-SWzs1) は Hypervariable region の同じ部位で 5 アミノ酸 の欠失がみられた，分子系統樹解析 (Fig. 1) でも静岡 株と上海株は近似していた。

\section{考察}

$\mathrm{E}$ 型急性肝炎が, ブタ, イノシシ, シカ等の肉や内臓 を加熱不十分な状態で摂取し発症する人畜共通の感染 症である事は，これまでの報告からも既に知られてい $ろ^{7) ~ 10)}$. 感染を確認する上で必要な HEV 関連の抗体測 定は保険適応が無い為, 診断に至るまでの過程におい て, HEV 流行地域への渡航歴とブタ, イノシシ, シカ 肉の摂取歴を聴取する事は重要である. 今回の 3 症例 も入院時の病歴聴取で, イノシシのレバー, シカ肉の 生食が確認され，迅速な診断が可能であった。

2006 年に行われた全国集計では, 感染源が確定ある いは推定された動物種ではブタ $66 \%$ ，イノシシ $23 \%$, シカ $8 \%$, 不明 $3 \%$ とブタが最も多いと報告されている ${ }^{2}$. シカ,イノシシは 11 月から 2 月の狩猟解禁時期以外に も鳥獣保護法（第 9 条）に基づき許可が得られれば有 害鳥獣として捕獲が認められている。浜松市森林課の 有害鳥獣捕獲の統計では平成 19, 20 年のイノシシ, シ カの捕獲頭数は 381 頭から 892 頭, 194 頭から 237 頭に それぞれ増加 ${ }^{11}$ している. 捕獲数の増加は感染機会の増 加に慗がる危険性もあり注意を促す必要があると考え られる。

$\mathrm{HEV}$ の感染性ついては $70^{\circ} \mathrm{C} 10$ 分およびそれ以上の温 度の加熱処理で不活化されると報告されている ${ }^{12}$. 生の 肉を一旦冷凍し, 後日解凍後, 調理して感染が成立し たと思われる報告もあり ${ }^{13}$, 冷凍保存された肉類につい ての取り扱いに関しても十分な注意が必要である。

静岡県からの $\mathrm{E}$ 型急性肝炎の症例報告は, 今回が初 めてとなる. 全国集計では, 北海道以外の地域では genotype 3 型が多い2) といわれているが，今回 genotype は全て 4 型であった。先に報告された隣県の愛知県で の 4 例の $\mathrm{E}$ 型急性肝炎の genotype は 4 型であり ${ }^{14}$, 愛 知, 長野県の野生イノシシから検出された遺伝子型の 調査結果でも genotype は 4 型と報告されている ${ }^{15)}$.

著者らの症例から分離された genotype $4 \mathrm{HEV} の 3$ 株はほぼ同一株であり，これら「4 型静岡株」は既報 $\lceil 4 \text { 型愛知株 }\rfloor^{14) 15)}$ とも高い相同性 $(98.5 \%-99.8 \%)$ を示 すため, 単一系統の $\lceil 4$ 型愛知静岡株」であると考える (Fig. 1a).「4 型静岡株」は, 完全長または準完全長塩 基配列の比較で 4 型国内株と異なり上海株に類似し(Fig. 1b), アミノ酸配列の hyper variable region で上海株と 共通の欠失を認める (Fig. 2) など, 系統解析において は国内株よりもむしろ上海株により近いことが示され た. 以上の事実は $\lceil 4$ 型愛知静岡株」と上海株は祖先を 共にする近縁 HEV 株であることを強く示唆しており, 
a) ORF1 326nt
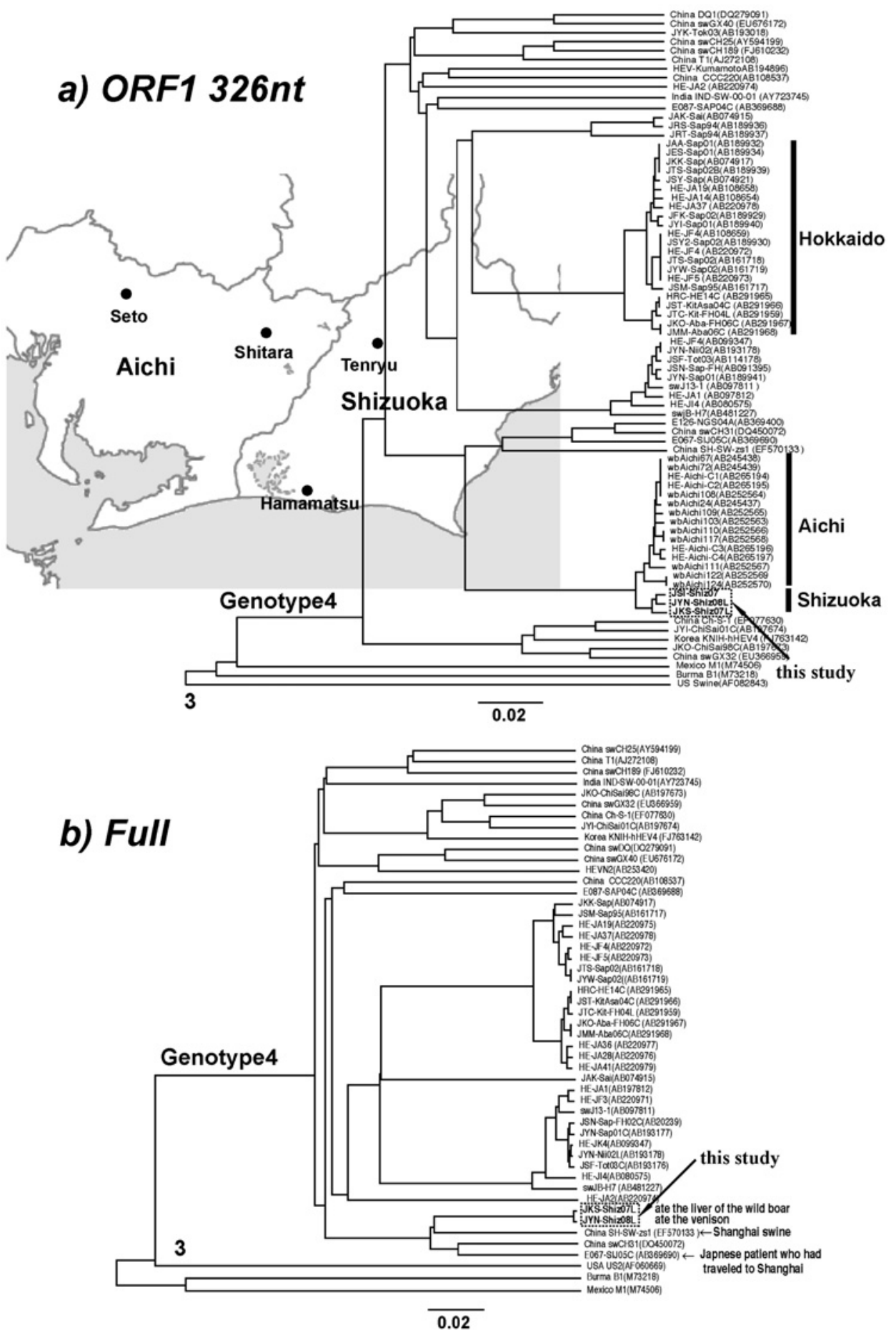

b) Full

Fig. 1 a) Phylogenetic tree showing the partial nucleotide sequences of the ORF1 region (326nt) of hepatitis $\mathrm{E}$ virus in 75 isolates by unweighted pair-grouping method with arithmetic means (UPGMA). b) Phylogenetic tree showing the complete or near-complete nucleotide sequences of hepatitis $\mathrm{E}$ virus in 50 isolates by UPGMA. 


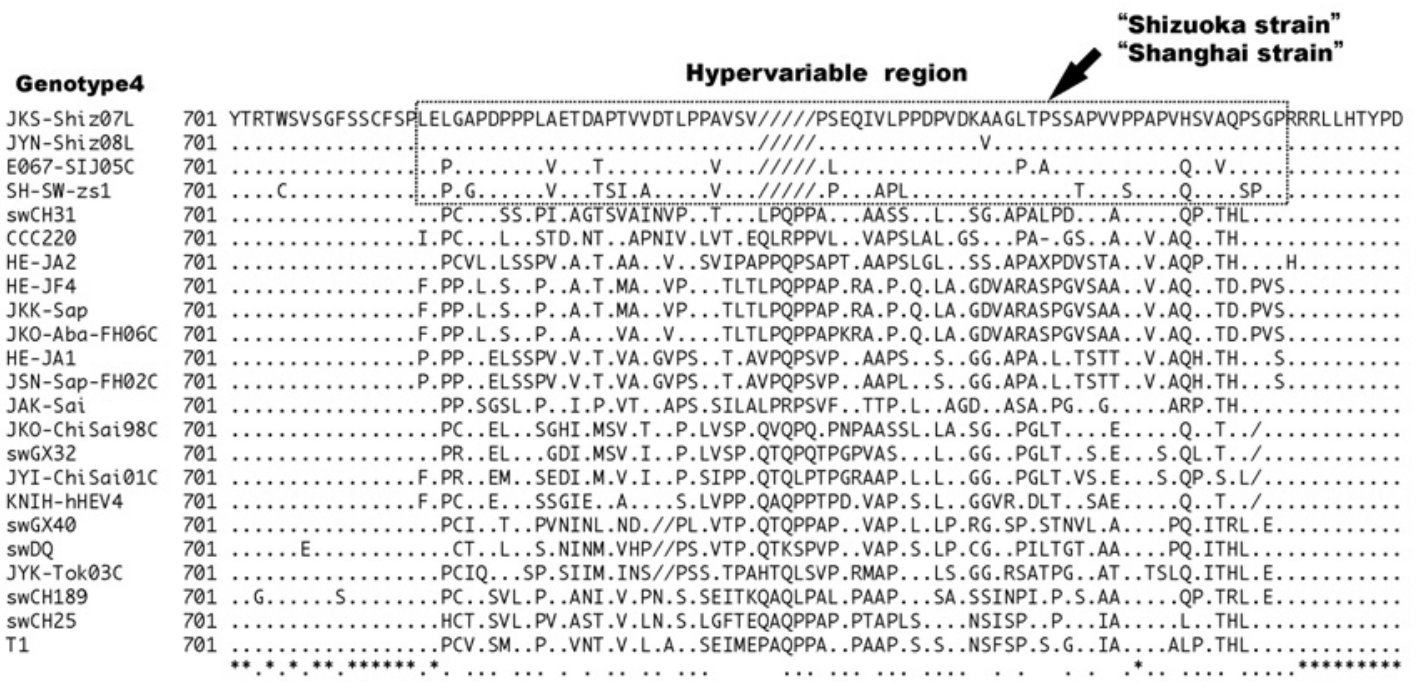

Fig. 2 Comparison of the amino acid sequences of hypervariable region in the ORF of hepatitis E virus genotype 4 isolates. The arrow indicates a box showing amino acid sequences of 'Shanghai strain' and 'Shizuoka strain'.

東海中部地区における genotype $4 \mathrm{HEV}$ は中国から伝搬 した可能性が存在する.

\section{文献}

1) Takahashi K, Iwata K, Watanabe N, et al. Fullgenome nucleotide sequence of a hepatitis $\mathrm{E}$ virus strain that may be indigenous to Japan. Viology 2001; 287: 9-12

2）阿部敏紀, 相川達也, 赤羽賢浩, 他. 本邦に於ける $\mathrm{E}$ 型肝炎ウイルス感染の統計学的・疫学的・ウイル 又学的特徵：全国集計 254 例に基づく解析．肝臟 $2006 ; 47: 384-391$

3) Takahashi M, Kusakai S, Mizuo H, et al. Simultaneous detection of immunoglobulin A (Ig A) and IgM antibodies against Hepatitis $\mathrm{E}$ virus (HEV) is highly specific for diagnosis of acute $\mathrm{HEV}$ infection. J Clin Microbiol 2005; 43: 49-56

4) Takahashi K, Kang JH, Ohnishi S, et al. Genetic heterogeneity of hepatitis $\mathrm{E}$ virus recovered from Japanese patients with acute sporadic hepatitis. J Infect Dis 2002; 185 (9): 1342-1345

5) Tanaka $Y$, Takahashi K, Orito E, et al. Molecular tracing of Japan-indigenous hepatitis $\mathrm{E}$ viruses. J Gen Virol 2006; 87: 949-954

6) Shen Q, Zhang W, Cao X, et al. Cloning of full genome sequence of hepatitis $\mathrm{E}$ virus of Shanghai swine isolate using RACE method. Virol J 2007; 4: 98

7）加藤 将, 種市幸二, 松林圭二. 焼肉店での会食後 に発生した $\mathrm{E}$ 型肝炎ウイルス集団感染：うち 1 例は劇症肝炎で死亡．肝臓 $2004 ； 45 ： 688$

8) Matsuda H, Okada K, Takahashi K, et al. Severe hepatitis $\mathrm{E}$ virus infection after ingestion of uncooked liver from a wild boar. J Infect Dis 2003; 188: 944

9) Tamada $Y$, Yano K, Yatsuhashi H, et al. Consumption of wild boar linked to cases of hepatitis E. J Hepatol 2004; 40: 869-870

10) Tei S, Kitajima N, Takahashi K, et al. Zoonotic transmission of hepatitis $\mathrm{E}$ virus from deer to human beings. Lancet 2003; 362: 371-373

11）浜松市森林動物被害対策事業報告書: 平成 20 年

12) Tanaka T, Takahashi M, Kusano E, et al. Development and evaluation of an efficient cell-culture system for Hepatitis E virus. J Gen Virol 2007; 88: 903— 911

13）井上 学, 道堯浩二郎, 高橋和明, 他. イノシシ肉 の摂取あるいは調理行為によって感染した疑いのあ る主婦に発生した急性 E 型肝炎の 1 例. 肝臓 2006 ； $47: 459-464$

14）清水裕子, 山田雅彦, 立松英純, 他. 愛知県内で捕 獲された野生イノシシ摂食後に発症した $\mathrm{E}$ 型肝炎 


\title{
Three cases of hepatitis $\mathrm{E}$ after eating deer meat or wild boar liver in West Shizuoka, Japan
}

\author{
Kinya Kawamura ${ }^{1)}$, Yoshimasa Kobayashi' ${ }^{1)}$, Kazuaki Takahashi' ${ }^{2)}$, Kenichi Souda ${ }^{1}$, \\ Shinichi Sumiyoshi ${ }^{1)}$, Kazuhito Kawata ${ }^{1)}$, Yurimi Takahashi ${ }^{1)}$, Satsuki Makino ${ }^{1)}$, \\ Hidenao Noritake ${ }^{1)}$, Hirotoshi Nakamura ${ }^{1)}$, Natsuki Abe ${ }^{2)}$, Masahiro Arai ${ }^{2}$
}

We experienced 3 cases of hepatitis E, where the patients developed their disease about two months after eating wild boar or deer captured in Shizuoka prefecture, Japan. All three were middle-aged men, and two ate raw wild boar's liver by chance in the same restaurant. One often ate the raw meat of deer in his son's hunting life. On admission, the hepatic dysfunction was mild in all of them (total bilirubin 1.0-10.0 mg/dl, AST 754-953 U/ l, ALT 696-1182 U/l, prothrombin time 78-113\%) and improved promptly with fluid infusion and rest. They were all positive for IgM and IgG HEV antibodies and HEV-RNA. Viral genome sequencing indicated that their HEV segregated to a cluster within genotype 4 , with $99.8 \%$ or greater identity to each other. Interestingly, these isolates showed 98.5-99.8\% identity to "Aichi Strain of HEV Genotype 4" previously recovered from humans and wild boars in Aichi prefecture, clearly different from those that are predominant in Japan, particularly in Hokkaido.

Key words: acute hepatitis HEV hepatitis E

1) Second Department of Medicine, Hamamatsu University School of Medicine

2) Department of Medical Sciences, Toshiba General Hospital

*Corresponding author: k7@hama-med.ac.jp 